\title{
CHANGES IN THE COMPOSITE STRUCTURE AND PARAMETERS AFTER AN EXPOSURE TO A SYNERGIC ACTION OF VARIOUS EXTREME CONDITIONS
}

\author{
SPREMINJANJE STRUKTURE IN PARAMETROV KOMPOZITOV \\ IZPOSTAVLJENIH SINERGISTIČNI AKTIVNOSTI RAZLIČNIH \\ EKSTREMNIH POGOJEV
}

\author{
Tomáš Melichar, Ámos Dufka, Jiř́i Bydžovský \\ Brno University of Technology, Faculty of Civil Engineering, Institute of Technology of Building Materials and Components, \\ Veveři 331/95, 60200 Brno, Czech Republic \\ melichar.t@fce.vutbr.cz
}

Prejem rokopisa - received: 2015-08-14; sprejem za objavo - accepted for publication: 2016-03-01

doi:10.17222/mit.2015.256

\begin{abstract}
The research presented in this paper is aimed at studying the properties of composites designed for a redevelopment of reinforced concrete structures where it is possible to expect an increased risk of fire, i.e., shock actions of extreme temperatures Such conditions may occur, for example, in transport constructions, particularly in tunnels. We have developed two recipes (formulas) for materials based on a polymer-cement matrix and a porous filler. These materials were subjected to cyclic freezing and de-freezing in combination with a water action. In terms of a long-term durability, we monitored the characteristics after 50 and 100 cycles. The impact of an increased humidity was not considered in this phase of the research. After testing the frost resistance, the bodies were dried up. Then, temperature shocks of $(400,600$ and 1000$){ }^{\circ} \mathrm{C}$ followed. The bodies were cooled down under control, with gradual temperature decreases. The reason for assessing the impact of these two exposure conditions on the properties of designed materials was mainly the use of the porous filler. This filler has a favourable effect on the temperature resistance. On the other hand, however, the frost resistance can be negatively affected in combination with water. Studying the influence of the above two exposures was carried out using the basic physico-mechanical and also physico-chemical methods. We also utilized analytical methods for assessing the microstructure. The structure was also examined using an innovative imaging technique allowing a three-dimensional visual assessment, which was primarily aimed at identifying faults of the structure.
\end{abstract}

Keywords: composite, polymer-cement matrix, cementitious supplementary material, high temperature, frost resistance, synergic, microstructure

Namen predstavljene raziskave je študij lastnosti kompozitov namenjenih obnovi betonskih zgradb, kjer je možno pričakovati povečano nevarnost požara in delovanje ekstremnih temperatur. Taki pogoji se lahko pojavijo, na primer, v prometnih konstrukcijah, posebno v tunelih. Razvili smo dva recepta (formuli) materialov, ki temeljijo na mešanici polimer-cement in poroznega polnila. Ti materiali so bili izpostavljeni cikličnemu zamrzovanju in odtajanju, v kombinaciji z delovanjem vode. V smislu dolge zdržljivosti, smo pregledali značilnosti po 50 in 100 ciklih. Vpliv povečanja vlažnosti v tem delu raziskav ni bil obravnavan. Po preizkušanju odpornosti na mraz, so bila telesa osušena. Sledili so temperaturni šoki na $(400,600$ in 1000$){ }^{\circ} \mathrm{C}$. Telesa so bila kontrolirano ohlajena, s postopnim zmanjšanjem temperature. Razlog za ocenjevanje učinka teh dveh pogojev izpostavitve na lastnosti materiala, je bila predvsem uporaba poroznega polnila. To polnilo ima ugoden vpliv na temperaturno obstojnost. Po drugi strani pa je lahko odpornost na zmrzal manjša v kombinaciji z vodo. Študij vpliva obeh načinov izpostavitve je bil izveden $\mathrm{z}$ uporabo osnovnih fizikalno-mehanskih in tudi fizikalno-kemijskih metod. Za ocenjevanje mikrostrukture smo uporabili tudi analitične metode. Struktura je bila preiskana $\mathrm{z}$ uporabo inovativne slikovne tehnike, ki omogoča tridimenzionalno vidno oceno, katere prvotni namen je bil identifikacija napak v strukturi.

Ključne besede: kompozit, mešanica polimer-cement, cementni nadomestni material, visoka temperatura, odpornost na zmrzal, sinergija, mikrostruktura

\section{INTRODUCTION}

Durability of building materials is one of the key aspects of their smooth function in a given structure. There are many factors that could realistically affect engineering constructions. These may include exterior climatic conditions, the presence of aggressive media as well as accidental exposure to high temperatures. In practice, consequently, we can even come across situations where the structure is loaded with cyclic exposures to water and frost followed by fire. When developed, the building materials intended for the environments with the said potential risks of random factors must therefore be verified in laboratories. The primary reason is the use of non-traditional raw materials. With regard to the environmental situation and price, these raw materials often come from alternative resources. Alternative raw materials are more or less characterized by the variability of parameters, including their composition. The choice of suitable compositions of polymer-cement composites destined for demanding exposure conditions is one of the basic prerequisites of their sufficient resistance and the expected building lifetime.

The development of cement composites for unfavourable environments was addressed by more authors, 
for example in studies. ${ }^{1-7}$ Regarding the use of a porous aggregate for cement composites, very interesting and significant findings were published in study. ${ }^{8}$ Here, the research focuses on the contact zone (or surface transition zone) of the porous aggregates and the cement matrix. The issue is dealt with in terms of both experimental research and numerical simulation. It is shown that this zone is less porous when using a lightweight aggregate with a smaller thickness than in the case of conventional dense aggregates. Depending on the watercement ratio and the structure of the aggregate surface layer or aggregate porous system, this matrix/aggregate transition zone is characterized by different parameters. For example, this zone disappears in the case of a very low water-cement ratio and the use of microsilica.

While exploring scientific literature and scientific articles, we did not find any publications that would present a research aimed at the synergistic effects of frost and subsequent high temperatures (simulating fire) on the composites containing a lightweight aggregate. The issue was only addressed separately. Interesting findings of authors dealing with the effects of high temperatures on cement composites are presented, inter alia, in studies. ${ }^{9-11}$

The parameters of a lightweight aggregate produced in self-firing processes from secondary energy products are studied in article. ${ }^{12}$

\section{METHODOLOGY OF THE EXPERIMENTAL WORK}

The research tested two recipes of repair materials based on a polymer-cement composite matrix. Specific formulations of recipes are given in the following table (Table 1).

Table 1: Compositions of tested mixtures

Tabela 1: Sestava preizkušenih mešanic

\begin{tabular}{|l|c|c|c|}
\hline \multirow{2}{*}{ Component } & \multirow{2}{*}{ Unit } & \multicolumn{2}{c|}{ Mixture } \\
\cline { 3 - 4 } & & RMS & RMA \\
\hline Cement & $\mathrm{kg} \mathrm{m}^{-3}$ & 435 & 435 \\
\hline Blast furnace slag & $\mathrm{kg} \mathrm{m}^{-3}$ & 234 & - \\
\hline Fly ash & $\mathrm{kg} \mathrm{m}^{-3}$ & - & 234 \\
\hline Vinyl acetate copolymer & $\%\left(\mathrm{w}_{\mathrm{cem}}\right)$ & 3 & 3 \\
\hline Microsillica & $\%\left(\mathrm{w}_{\mathrm{cem}}\right)$ & 5 & 5 \\
\hline Amphibolite 0-1 $\mathrm{mm}$ & $\mathrm{kg} \mathrm{m}^{-3}$ & 837 & 837 \\
\hline Porous aggregate $1-2 \mathrm{~mm}$ & $\mathrm{~kg} \mathrm{~m}^{-3}$ & 632 & 632 \\
\hline Polypropylene fibres & $\mathrm{kg} \mathrm{m}^{-3}$ & 1,0 & 1,0 \\
\hline Water & $\mathrm{kg} \mathrm{m}^{-3}$ & $187^{*}$ & $187^{*}$ \\
\hline
\end{tabular}

* The porous aggregate was saturated with water before preparing the mixtures. The aggregate has a water-absorption ability of about $35 \%$. So, a certain amount of water was leached from the porous aggregate during the mixing.

The polymeric additive based on a copolymer of vinyl acetate and ethylene in an amount of $3 \%$ of the cement weight was used in order to improve the cohesion in the fresh as well as hardened state, and the plasti- city of the fresh mixture. The filler was an amphiboliteaggloporite mixture, which is an artificially produced porous sintered aggregate (hereinafter referred to as aggloporite).

Since these materials were fine-grained mortars, the testing was performed on bodies with dimensions of (40 $\times 40 \times 160) \mathrm{mm}$. The first group of these bodies was exposed to 50 freezing cycles with a subsequent thermal load, followed by a definition of the essential characteristics according to ${ }^{13-15}$. The second group of the bodies was exposed to 100 freezing cycles followed by a thermal load and an assessment of the parameters. The exposure under the conditions of alternating freezing and de-freezing was carried out according to ${ }^{16}$. Cycling was implemented so that the tests of the characteristics were conducted after $70 \mathrm{~d}$ or $120 \mathrm{~d}$. In these ages, we also tested reference bodies that had been only exposed to extreme temperatures.

The thermal exposure was carried out in steps of (400, 600 and 1000) ${ }^{\circ} \mathrm{C}$. The cooling took place gradually in furnaces with a decreasing gradient of about $1{ }^{\circ} \mathrm{C} \mathrm{min}^{-1}$. Laboratory-stored bodies were exposed continuously to about $22{ }^{\circ} \mathrm{C}$. In addition to the basic material properties and microstructure, the mortars were also visually assessed.

\section{RESULTS}

A comparison of the achieved outputs is shown in the graphs below (Figures 1 to 6). An emphasis was placed on the assessment of the bulk density (designated as

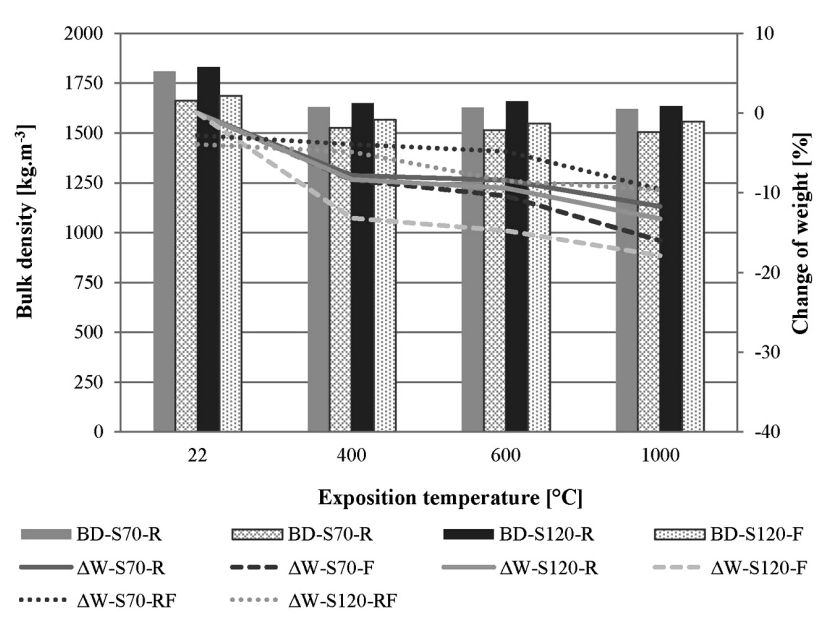

Figure 1: Bulk density and weight change of mixture RMS containing blast furnace slag (BD - bulk density; W - weight; S70(120)-R - reference composite after 70 (120) days and thermal exposure; S70(120)-F - composite after 70 (120) days or 50 (100) frost cycles and thermal exposure; S70(120)-RF - difference between reference and frostexposed specimens)

Slika 1: Gostota osnove in spreminjanje teže mešanice RMS, ki vsebuje plavžno žlindro (BD - gostota osnove, W - teža; S70(120)-R referenčni kompozit po 70 (120) dneh toplotne izpostavitve; S70(120)-F - kompozit po 70 (120) dnevih ali 50 (100) ciklih zamrzovanja in toplotne izpostavitve; $S 70(120)-\mathrm{RF}$ - razlika med referenčnim vzorcem in vzorcem izpostavljenem zamrzovanju) 
T. MELICHAR et al.: CHANGES IN THE COMPOSITE STRUCTURE AND PARAMETERS AFTER AN EXPOSURE ...

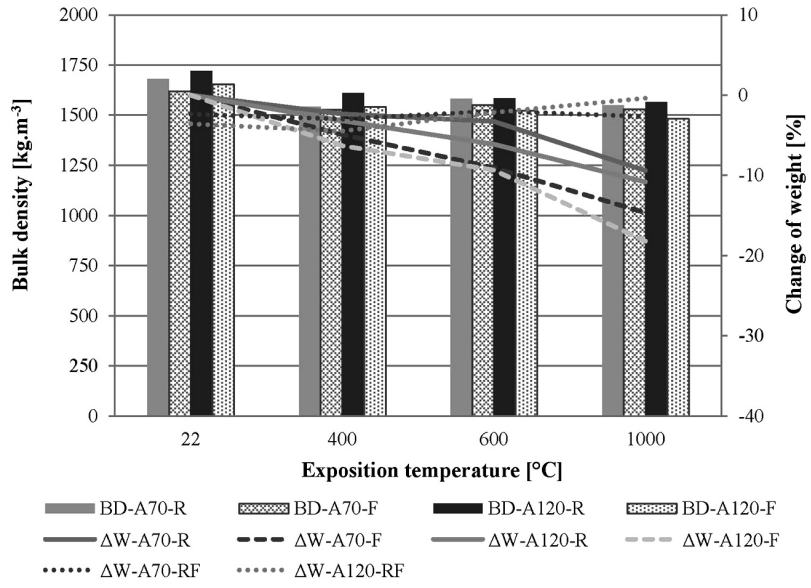

Figure 2: Bulk density and weight change of mixture RMA containing fly ash (BD - bulk density; W - weight; A70(120)-R reference composite after 70 (120) days and thermal exposure; A70(120)-F - composite after 70 (120) days or 50 (100) frost cycles and thermal exposure; A70(120)-RF - difference between reference and frost-exposed specimens)

Slika 2: Gostota osnove in spreminjanje teže RMA, ki vsebuje leteči pepel (BD - gostota osnove, W - teža; A70(120)-R - referenčni kompozit po 70 (120) dneh toplotne izpostavitve; A70(120)-F - kompozit po 70 (120) dneh ali 50 (100) ciklih zamrzovanja in toplotne izpostavitve; A70(120)-RF - razlika med referenčnim vzorcem in vzorci po toplotni izpostavitvi)

BD), weight (designated as W) and strength characteristics (designated as $\mathrm{fc}-$ compressive strength and $\mathrm{ff}-$ bending tensile strength). The courses of each recipe and parameter are evaluated separately. Each graph always contains a comparison of one recipe and the studied characteristic at the ages of $70 \mathrm{~d}$ and $120 \mathrm{~d}$. Courses of percentage changes (parameters designated as $\Delta$ ) of a given characteristic due to the exposure to the alternating

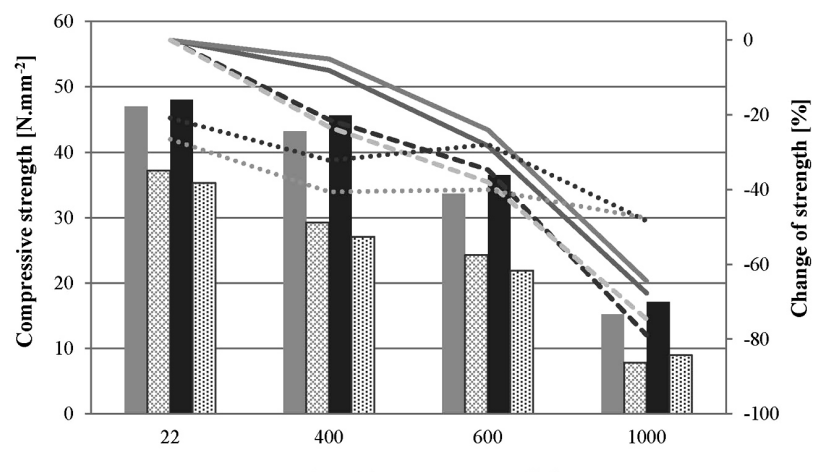

Exposition tempereture $\left[{ }^{\circ} \mathbf{C}\right]$

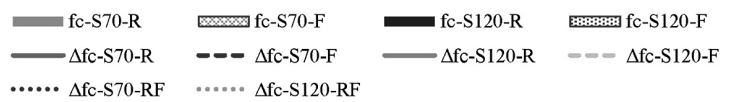

Figure 3: Compressive strength of mixture RMS containing blast furnace slag (S70(120)-R - reference composite after 70 (120) days and thermal exposure; S70(120)-F - composite after 70 (120) days or 50 (100) frost cycles and thermal exposure; S70(120)-RF - difference between reference and frost-exposed specimens)

Slika 3: Tlačna trdnost mešanice RMS, ki vsebuje plavžno žlindro (S70(120)-R - referenčni kompozit po 70 (120) dneh toplotne izpostavitve; S70(120)-F - kompozit po 70 (120) dneh ali 50 (100) ciklih zamrzovanja in toplotni izpostavitvi; S70(120)-RF - razlika med referenčnim in zamrzovanju izpostavljenim vzorcem)

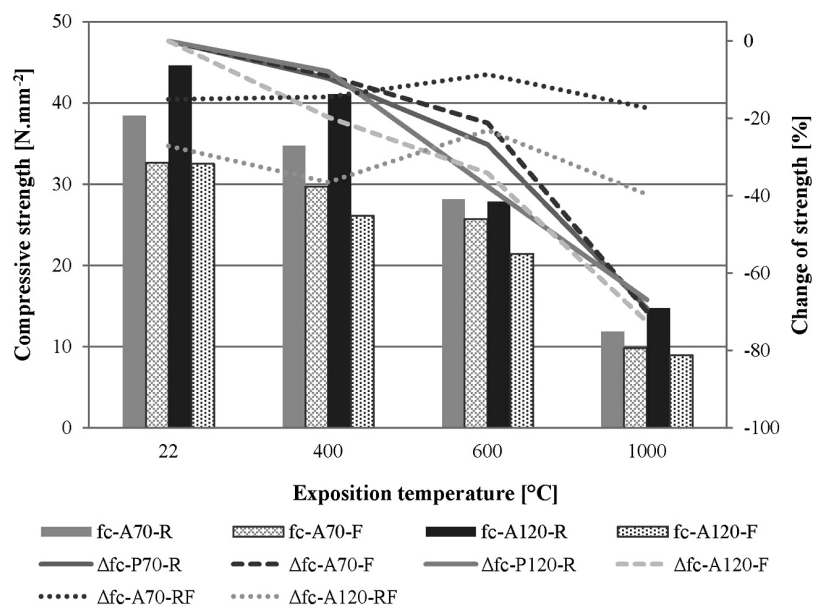

Figure 4: Compressive strength of mixture RMA containing fly ash (A70(120)-R - reference composite after 70 (120) days and thermal exposure; A70(120)-F - composite after 70 (120) days or 50 (100) frost cycles and thermal exposure; A70(120)-RF - difference between reference and frost-exposed specimens)

Slika 4: Tlačna trdnost mešanice RMA, ki vsebuje leteči pepel (A70(120)-R - referenčni kompozit po 70 (120) dneh toplotne izpostavitve; A70(120)-F - komozit po 70 (120) dneh ali 50 (100) ciklih zamrzovanja in toplotne izpostavitve; A70(120)-RF - razlika med referenčnim in zamrzovanju izpostavljenim vzorcem)

freezing and de-freezing with a subsequent thermal shock are plotted on the secondary axis (solid and dashed curves). Furthermore (shown with a dotted curve), the graphs indicate differences in the reference parameters (designated as $\mathrm{R}$ ) for the frozen (designated as F) bodies after each temperature exposure (difference - designated as RF).

Fluctuations of negative temperatures in combination with a saturation of the material with water and the
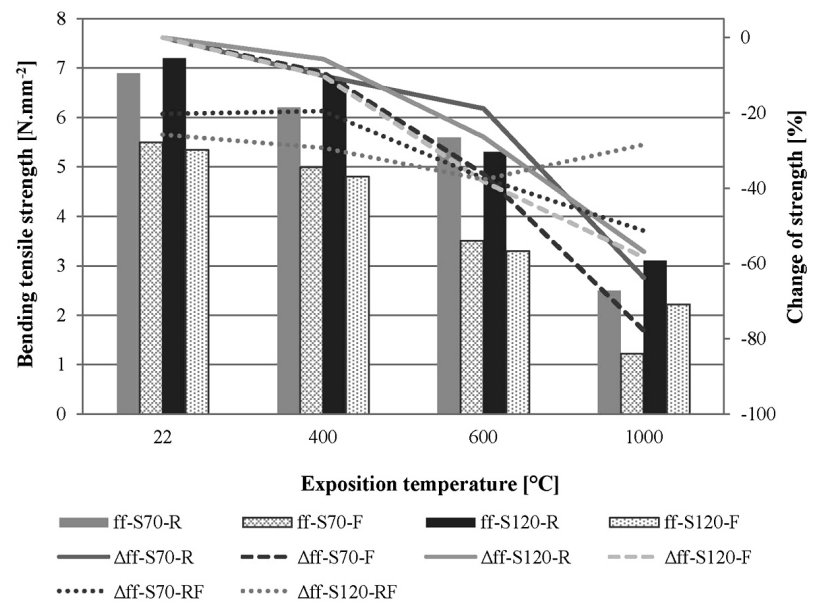

Figure 5: Flexural strength of mixture RMS containing blast furnace slag (S70(120)-R - reference composite after 70 (120) days and thermal exposure; S70(120)-F - composite after 70 (120) days or 50 (100) frost cycles and thermal exposure; S70(120)-RF - difference between reference and frost-exposed specimens)

Slika 5: Upogibna trdnost mešanice RMS, ki vsebuje plavžno žlindro (S70(120)-R - referenčni kompozit po 70 (120) dneh toplotne izpostavitve; S70(120)-F - komozit po 70 (120) dneh ali 50 (100) ciklih zamrzovanja in toplotne izpostavitve; S70(120)-RF - razlika med referenčnim in zamrzovanju izpostavljenim vzorcem) 
T. MELICHAR et al.: CHANGES IN THE COMPOSITE STRUCTURE AND PARAMETERS AFTER AN EXPOSURE ...

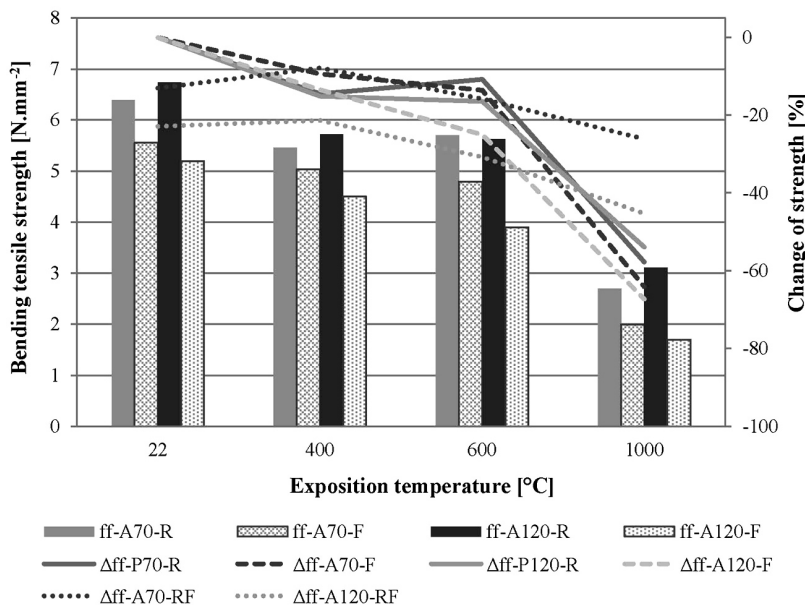

Figure 6: Flexural strength of mixture RMA containing fly ash (A70(120)-R - reference composite after 70 (120) days and thermal exposure; A70(120)-F - composite after 70 (120) days or 50 (100) frost cycles and thermal exposure; A70(120)-RF - difference between reference and frost-exposed specimens)

Slika 6: Upogibna trdnost mešanice RMA, ki vsebuje plavžno žlindro (A70(120) - R - referenčni kompozit po 70 (120) dneh toplotne izpostavitve; A70(120) - F - kompozit po 70 (120) dneh ali 50 (100) ciklih zamrzovanja in toplotne izpostavitve; A70(120) - RF - razlika med referenčnim in zamrzovanju izpostavljenim vzorcem)

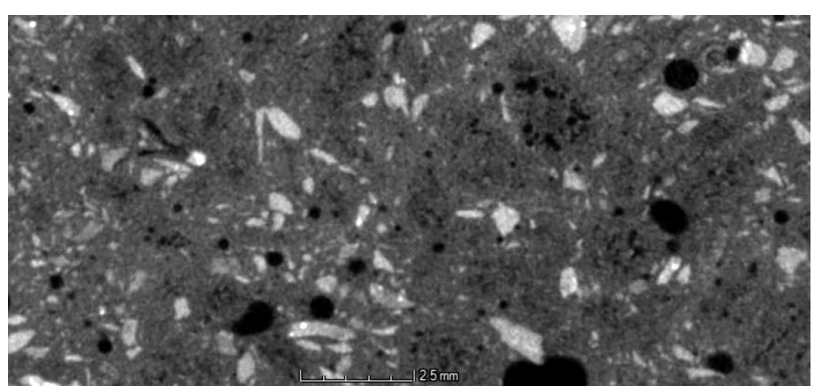

Figure 7: CT image - slice of RMA, 120 days, $\mathrm{R}$ - reference sample (without freezing cycles), exposure to $1000^{\circ} \mathrm{C}$

Slika 7: CT-posnetek rezine RMA, 120 dni, R - referenčni vzorec (brez ciklov zamrzovanja), izpostavljen na $1000{ }^{\circ} \mathrm{C}$

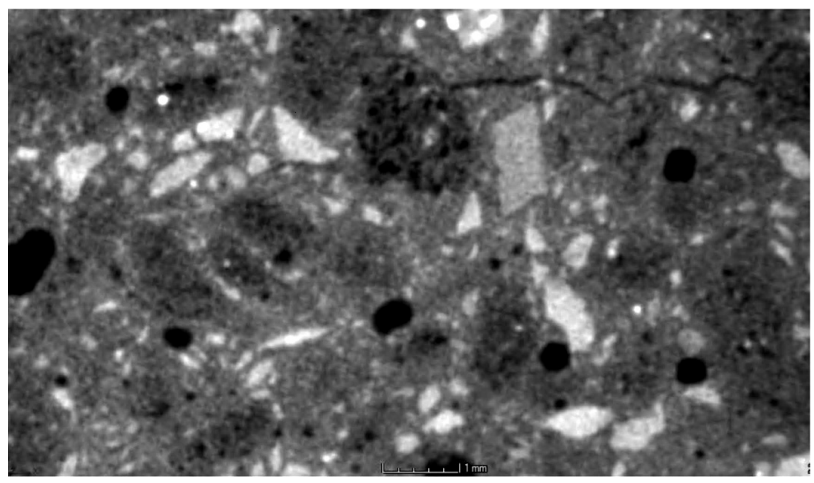

Figure 8: CT image - slice of RMA, 120 days, R - reference sample, 100 freezing cycles, exposure to $1000{ }^{\circ} \mathrm{C}$

Slika 8: CT-posnetek rezine RMA, 120 dni, R - referenčni vzorec po 100 ciklih zamrzovanja, izpostavljen na $1000^{\circ} \mathrm{C}$

subsequent thermal load may lead to cracks or microcracks. For this reason, one of the key included analytical methods was computer tomography (hereinafter

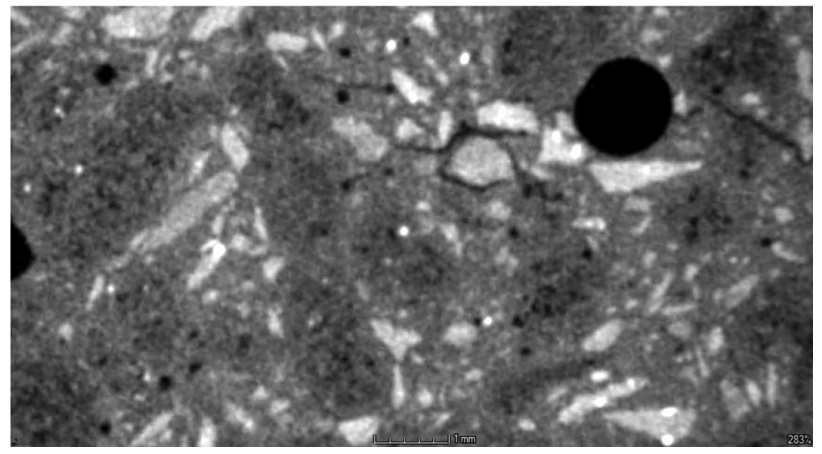

Figure 9: CT picture - slice of RMS, 120 days, R - reference sample, 100 freezing cycles, exposure to $1000{ }^{\circ} \mathrm{C}$

Slika 9: CT-posnetek rezine RMS, 120 dni, R - referenčni vzorec po 100 ciklih zamrzovanja, izpostavljen na $1000{ }^{\circ} \mathrm{C}$

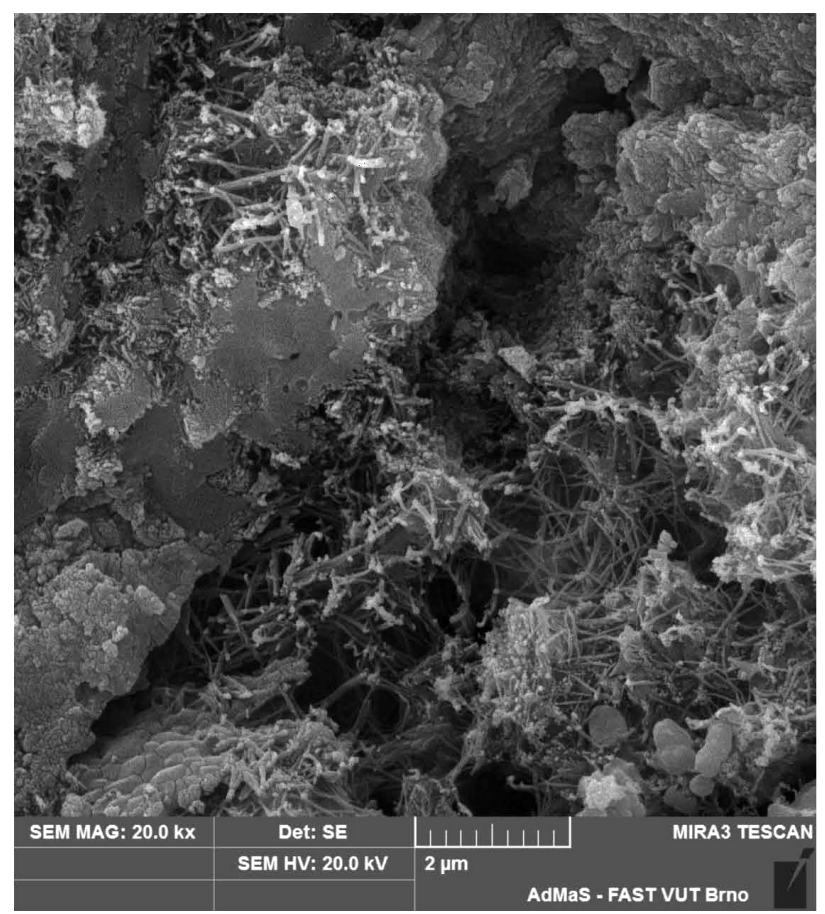

Figure 10: Microstructure of RMS, exposure temperature of $1000{ }^{\circ} \mathrm{C}$ (without freezing), mag. 20.000x; detail of structure degradation

Slika 10: Mikrostruktura RMS, temperature izpostavitve $1000{ }^{\circ} \mathrm{C}$ (brez zamrzovanja), pov. 20,000×; detajl degradacije strukture

referred to as CT). Figures below present selected images of the bodies loaded with a temperature of $1000{ }^{\circ} \mathrm{C}$ including the reference bodies (Figures 7 to 9). Another substantial analysis was electron microscopy (hereinafter referred to also as SEM). Here, the attention was focused on the faults of the matrix itself as well as on any microscopic cracks, mainly in the matrix-filler interface (Figures 9 and 10).

\section{DISCUSSION}

The RMS formula gave us bulk-density values (Figure 1) of $1810 \mathrm{~kg} \cdot \mathrm{m}^{-3}$ and $1830 \mathrm{~kg} \cdot \mathrm{m}^{-3}$ after $70 \mathrm{~d}$ or 120 
d, respectively. Therefore, an almost negligible growth was observed. For a proper evaluation (in terms of requirements of normative documents), the graph (Figure 1) also contains curves characterizing the weight loss. The course of the curves indicates that the resistance to high temperatures gradually gently decreased due to the frost cycles. After 100 cycles and exposure to an ambient temperature of $1000{ }^{\circ} \mathrm{C}$, we observed a weight loss of $17.9 \%$ while the reference material showed a decrease of about $13.3 \%$. Differences between the weight losses (RF curve, Figure 1) after 100 frost cycles were identified as slightly higher. After exposure to $1000{ }^{\circ} \mathrm{C}$, however, the differences in the weight loss (RF curve, Figure 1) after 50 and 100 cycles became equal.

The RMA formula was characterized by bulk-density values of $1680 \mathrm{~kg} \cdot \mathrm{m}^{-3}$ and $1720 \mathrm{~kg} \cdot \mathrm{m}^{-3}$ after $70 \mathrm{~d}$ and $120 \mathrm{~d}$, respectively (Figure 2). As in the case of the RMS recipe, this parameter increases very slightly. The courses of weight decreases are different in comparison with the RMS formula. The R and F curves can be characterized by a more uniform and more gradual decline than in the case of the RMS. Nevertheless, the weight losses after 100 frost cycles followed by the thermal exposure of $1000{ }^{\circ} \mathrm{C}$ are comparable for both recipes (about $18 \%$ ), i.e., the influences of fly ash and slag are similar (with a negligible difference of $0.3 \%$ in favour of the slag). The RF curves show a relatively balanced course.

In comparison with the weight, the declines in strength characteristics were much more noticeable. In the case of the RMS recipe, 50 frost cycles led to a decrease in the compressive strength by about $21 \%$ (from the original value of about $47 \mathrm{~N} \cdot \mathrm{mm}^{-2}$ ) and 100 cycles resulted in a decrease by $26.5 \%$ (from the original value of $48 \mathrm{~N} . \mathrm{mm}^{-2}$; Figure 3). According to the relevant technical standard, ${ }^{16}$ the essential criterion for a decrease is $25 \%$; this criterion was slightly exceeded after 100 cycles. When comparing the $\mathrm{R}$ and $\mathrm{F}$ curves characterizing the loss of strength due to the thermal stress or frost stress, it is evident that the influence of the cyclic frost was manifested by pronounced declines. The difference between the exposures at 50 or 100 cycles is not very noticeable. The graph clearly shows that 100 frost cycles followed by a thermal load at the age of 120 d caused a decrease in the compressive strength to $74.6 \%$, i.e., the residual strength of $24.4 \%$ (or $9 \mathrm{~N} \mathrm{~mm}^{-2}$ ). Exposure to the temperature of $1000{ }^{\circ} \mathrm{C}$ resulted in virtually identical residual strengths (Figure 3, RF curves).

In the RMA recipe, the trends of the compressive strength are not so clear (Figure 4). The values show a significant increase in the strength owing to a longer ripening time. This was partly expected due to the nature of fly ash because of its involvement in the hydration process occurring after a prolonged period of time. Due to the frost stress (without the temperature exposure), the compressive strength decreased by $15.1 \%$ and $27.1 \%$ after 50 cycles and 100 cycles, respectively. The difference is thus slightly greater than for the RMS recipe. The $\mathrm{R}$ and $\mathrm{F}$ curves follow a similar pattern; after the exposure at $1000{ }^{\circ} \mathrm{C}$, it is possible to record almost the same values of the residual compressive strength, i.e., around $30 \%\left(9-10 \mathrm{~N} . \mathrm{mm}^{-2}\right)$. Regarding the compressive strength, therefore, the resistance of the composite matrix based on fly ash can be evaluated better compared to the case of using slag.

The bending tensile strength of the RMS recipe reached 6.9 N.mm ${ }^{-2}$ and 7.2 N.mm ${ }^{-2}$ after $70 \mathrm{~d}$ and 120 d, respectively (Figure 5). Due to the frost cycles, the strength decreased by $20 \%$ and $25.8 \%$ after 50 cycles and 100 cycles, respectively (without the thermal load). Except for the 70-day exposure to frost with a subsequent thermal load, the residual strengths (after 1000 ${ }^{\circ} \mathrm{C}$ ) ranged around the value of $40 \%$.

The bending tensile strength of the RMA recipe was around 6.4 N.mm ${ }^{-2}$ after 50 cycles and 6.7 N.mm ${ }^{-2}$ after 100 freezing and de-freezing cycles. The residual strengths after the frost cycles with a subsequent high temperature load were determined in a range of 33-36 \%. The bodies loaded only thermally retained $42-46 \%$ of the bending strength. The results show that the residual bending tensile strengths in the RMS and RMA recipes do not differ significantly. Only the courses of the RF curves are distinctly different.

The CT analysis focused on the structure degradation, both in the individual components and their

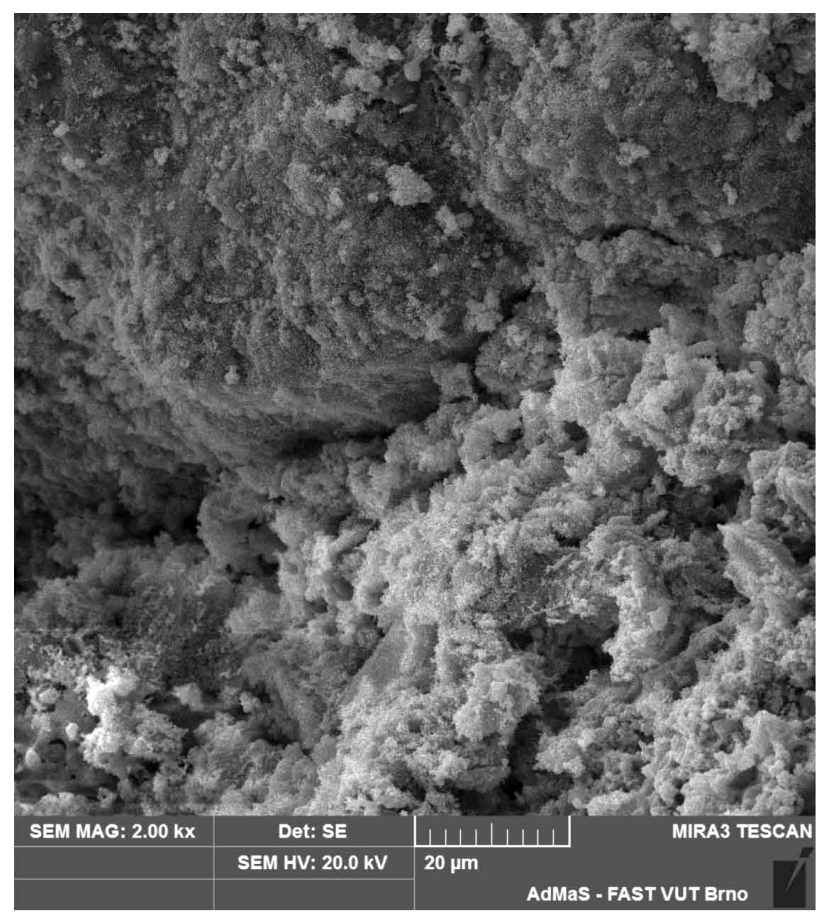

Figure 11: Microstructure of RMS, exposure to 100 freezing cycles and then the temperature of $1000{ }^{\circ} \mathrm{C}$, mag. 2.000x; detail of a crack Slika 11: Mikrostruktura RMS, izpostavitev 100 ciklom zamrzovanja in nato na temperaturi $1000{ }^{\circ} \mathrm{C}$, pov: $2,000 \times$; detajl razpoke 
contact zones. It was found that the bodies exposed to frost and then to high temperatures show a slightly increased incidence of cracks. In comparison with the bodies exposed to a high temperature without the cyclical freezing, however, the difference was not too pronounced. Identified cracks were located primarily in the matrix, at the interface of the dense aggregate and the matrix, and - to a lesser extent - in the porous aggregate (Figures 7 to 9). As for the incidence of cracks, the differences between the RMA and RMS recipes were almost negligible.

The microstructural method was mainly used to identify the matrices gradually degrading with the increasing temperature (Figures $\mathbf{1 0}$ and 11). No differences between the bodies exposed and not exposed to frost were observed. Likewise, there was no significant difference in the microstructure of the samples after $70 \mathrm{~d}$ and $120 \mathrm{~d}$ or after 50 and 100 frost cycles. It is therefore evident that the frost is more likely to distort the structure on the "macroscopic" scale without microstructural changes, while the thermal exposure also supports the decomposition of hydration complexes and possibly the emergence of new products. This could particularly occur in the case of fly ash, which might act as a flux if the contents of iron or alkalis are increased.

Hydration of fly ash or its involvement in the hydration reactions during the silica-matrix ripening requires longer times. According to normative documents, the influence of fly ash applied to the concrete is tested after $28 \mathrm{~d}$ and $90 \mathrm{~d}$. In the case of a shorter time period, it is therefore possible that the greater portion of fly ash could act as a flux without any significant contribution to shaping the silicate-matrix structure. After a longer period, conversely, the greater portion of fly ash could hydrate, which would theoretically reduce its ability as a flux. Alternatively, if the ability as a flux remained while the participation in hydration reactions was demonstrable, the positive effect of fly ash would be clear. In this case, however, it would be necessary to verify the specific amounts of fly ash depending on its chemical composition in order to avoid the melting of the composite at a certain temperature to an extent that would cause the loss of its carrying capacity. For this reason, it would be appropriate to supplement the performed analyses with heat microscopy.

\section{CONCLUSIONS}

With regard to the achieved results, we can say that both developed recipes are resistant to the action of extreme temperature conditions, i.e., the combination of frost and the subsequent high temperatures. However, this only applies to 50 frost cycles. After an exposure to 100 cycles, the limit criterion of $25 \%$ (the minimum residual strength of $75 \%$ ) was slightly exceeded. Frost resistance is partially limited by the use of lightweight porous aggregates. Within the following research, it would be useful to focus on optimizing the composition of recipes in terms of a long-term resistance to frost. Taking into account the conditions of the application of the developed materials, however, it would also be possible to consider secondary protection, i.e., surface treatment by painting. This could increase the resistance to frost. It is important to find that the temperature resistance was not affected to a striking extent despite the decline in the strengths in the order of about 15-27\% due to frost - the trend of the residual strengths.

Higher strengths (without exposures to extreme conditions) were reached in the recipe containing slag, i.e., the RMS. In the case of the RMA recipe, a pronounced incidence of strength characteristics was more apparent in the longer term. The RMA recipe showed improved temperature resistance. This is demonstrated by the determined residual strengths, especially the compressive strengths at $1000{ }^{\circ} \mathrm{C}$, where we observed residual strengths of almost $30 \%$. This fact is not so explicit in the case of bending strengths. The benefit of the presented research, among other things, is the composition of the recipes. It was a combination of commercially produced (i.e., available) primary as well as alternative raw materials - in terms of both matrix and filler.

To clarify the behaviour of fly ash in the given matrix under extreme conditions, it would be appropriate to include other additional analyses. Studying properties of the developed composites under simultaneous effects of extreme temperatures and their mechanical stress (compression or tensile bending) seems to be very interesting. This could prove whether the an increasing temperature and the related structural changes including degradation of the matrix or other components lead to a total loss of the carrying capacity of the respective material before it becomes cold.

\section{Acknowledgements}

This article was made with the financial support of The Czech Science Foundation (GAČR) project 14-25504S "Research of Behaviour of Inorganic Matrix Composites Exposed to Extreme Conditions", as well as under the project No. LO1408 "AdMaS UP - Advanced Materials, Structures and Technologies", supported by Ministry of Education, Youth and Sports under the "National Sustainability Programme I".

\section{REFERENCES}

${ }^{1}$ N. U. Kockal, T. Ozturan, Durability of lightweight concretes with lightweight fly ash aggregates, Construction and Building Materials, 25 (2011) 3, 1430-1438, doi:10.1016/j.conbuildmat.2010.09.022

${ }^{2}$ B. Kucharczyková, Z. Keršner, O. Pospíchal, P. Misák, P. Daněk, P. Schmid, The porous aggregate pre-soaking in relation to the freezethaw resistance of lightweight aggregate concrete, Construction and Building Materials, 30 (2012) 761-766, doi:10.1016/j.conbuildmat. 2011.12.067

${ }^{3}$ H. Garbalińska, A. Wygocka, Microstructure modification of cement mortars: Effect on capillarity and frost-resistance, Construction and Building Materials, 51 (2014), 258-266, 10.1016/j.conbuildmat. 2013.10.091 


\section{MATERIALI IN TEHNOLOGIJE/MATERIALS AND TECHNOLOGY (1967-2017) - 50 LET/50 YEARS}

\section{T. MELICHAR et al.: CHANGES IN THE COMPOSITE STRUCTURE AND PARAMETERS AFTER AN EXPOSURE ...}

${ }^{4}$ S. Rahman, Z. Grasley, A poromechanical model of freezing concrete to elucidate damage mechanisms associated with substandard aggregates, Cement and Concrete Research, 55 (2014), 88-101, doi:10.1016/j.cemconres.2013.10.001

${ }^{5}$ S. Chandra, L. Berntsson, 10 - Freeze-Thaw Resistance of Lightweight Aggregate Concrete, in Lightweight Aggregate Concrete, edited by Satish Chandra and Leif Berntsson, William Andrew Publishing, Norwich, NY, 2002, 321-368, doi:10.1016/B978081551486-2.50013-4

${ }^{6}$ M. B. Karakoç, R. Demirboğa, İ. Türkmen, İ. Can, Modeling with ANN and effect of pumice aggregate and air entrainment on the freeze-thaw durabilities of HSC, Construction and Building Materials, 25 (2011) 11, 4241-4249, doi:10.1016/j.conbuildmat. 2011.04.068

${ }^{7}$ S. Chandra, J. Aavik, L. Berntsson, Influence of polymer microparticles on freeze-thaw resistance of structural lightweight aggregate concrete, International Journal of Cement Composites and Lightweight Concrete, 4 (1982) 2, 111-115, doi:10.1016/0262 5075(82)90015-X

${ }^{8}$ Y. Ke, S. Ortola, A. L. Beaucour, H. Dumontet, Identification of microstructural characteristics in lightweight aggregate concretes by micromechanical modelling including the interfacial transition zone (ITZ), Cement and Concrete Research, 40 (2010) 11, 1590-1600, doi:10.1016/j.cemconres.2010.07.001

${ }^{9}$ J.-P. Won, H.-B. Kang, S.-J. Lee, S.-W. Lee, J.-W. Kang, Thermal characteristics of high-strength polymer-cement composites with lightweight aggregates and polypropylene fiber, Construction and Building Materials, 25 (2011) 10, 3810-3819, doi:10.1016/ j.conbuildmat.2011.03.023
${ }^{10}$ F. Koksal, O. Gencel, M. Kaya, Combined effect of silica fume and expanded vermiculite on properties of lightweight mortars at ambient and elevated temperatures, Construction and Building Materials, 88 (2015), 175-187, doi:10.1016/j.conbuildmat.2015.04.021

${ }^{11} \mathrm{~S}$. Aydın, Development of a high-temperature-resistant mortar by using slag and pumice, Fire Safety Journal, 43 (2008) 8, 610-617, doi:10.1016/j.firesaf.2008.02.001

${ }^{12}$ V. Černý, Š. Keprdová, Usability of fly ashes from Czech Republic for sintered artificial aggregate, Advanced Materials Research, (2014), 805-808, doi:10.4028/www.scientific.net/AMR.887-888.805

${ }^{13}$ C SN EN 12190. Products and systems for the protection and repair of concrete structures - Test methods - Determination of compressive strength of repair mortar. ČNI, 1999

${ }^{14}$ ČSN EN 196-1. Methods of testing cement - Part 1: Determination of strength. ČNI, 2005

${ }^{15}$ ČSN EN 1504-3. Products and systems for the protection and repair of concrete structures - Definitions, requirements, quality control and evaluation of conformity - Part 3: Structural and non-structural repair. ČNI, 2006

${ }^{16}$ ČSN 73 1322, including Z1. Determination of frost resistance of concrete. ČNI, 2003 